\title{
CONSTITUTIONAL INTERPRETATION OR CONSTRUCTION OF THE GOVERNMENT-FORMATION PROCESS IN KOSOVO
}

Assoc. Prof. Behar Selimi, Ph.D.*

Assist. Prof. Murat Jashari, Ph.D.**
UDK: 342.41:342.51(497.115)

34.042:342.41(497.115)

DOI: 10.3935/zpfz.71.6.03

Izvorni znanstveni rad

Primljeno: prosinac 2021.

This article analyzes the constitutional provisions and practices of the Kosovar process of forming a government in two scenarios: after a parliamentary election, and after a motion of no confidence. The factors that most prominently complicate this process are the proportional electoral system, extreme party pluralism, and ambiguous constitutional provisions. Leaving aside the first two factors, which have thus far resisted efforts to change them, the authors claim that the constitutional law dealing with the government-formation process has undergone both procedural and substantive changes as a result of interpretations and decisions by the Constitutional Court. The authors further note that these changes are constitutional constructions, rather than constitutional interpretations, and describe the novel, resultant practice as legitimized without amendment. These constitutional interpretations and constructions, their possible alternatives, and the relevant constitutional provisions are analyzed through doctrinal legal research. That constitutional judgments can be reinterpreted and abused by interim, and office-seeking (rather than policy-seeking) political coalitions seems a condition poised to engender future instability; therefore, the authors hold that the amendment of the constitution is the best insurance against

* Behar Selimi, Ph.D., Associate Professor, Faculty of Law, UBT College, Lagjja Kalabria, 10000 Prishtinë, Kosovo; bselimi@hotmail.com.

ORCID ID: orcid.org/0000-0002-3070-6720

** Murat Jashari, Ph.D., Assistant Professor, Faculty of Law, University of Prishtina, Rr. “Agim Ramadani”, 10000 Prishtinë, Kosovo; muratjashari@hotmail.com.

ORCID ID: orcid.org/0000-0003-1502-8279 
political and constitutional crises when it comes to forming a government, either after elections or with the same legislature. The authors hope that this paper will contribute to the enrichment of the constitutional practice of forming parliamentary governments and the development of the doctrine of constitutional interpretation.

Keywords: constitutional interpretation, constitutional construction, government-formation, Constitution of Kosovo, Constitutional Court

\section{INTRODUCTORY REMARKS}

Kosovo's democracy is one of the youngest in the world, as is the state itself. Its model is unique in that it relies on the division of power between ethnic communities. ${ }^{1}$ The constitutional requirement of interethnic co-government gives Kosovo the character of a "state of communities" rather than a "state of its citizens". ${ }^{2}$ This model, promoted many years ago by Arend Ljiphart ${ }^{3}$, was imposed by the international community to "promote the building of lasting peace and the structuring of the foundations for the development of democracy'. ${ }^{4}$ Precisely these objectives were the priority in post-war Kosovo - which was deeply divided across not only ethnic but also political lines - and they would later become the objectives of its constitution as well. ${ }^{5}$

Although not explicitly defined as such in its constitution, a simple analysis of Kosovo's formation, functioning, and separation of powers shows the state to be a parliamentary republic. Though we may in fact find elements of a semi-presidential republic in the powers of the president, or atypical parliamentary elements in the prime minister's powers and key functions with respect to political decision-making, the presence of such elements is insufficient to characterize Kosovo as falling under any type or sub-type of semi-presidential-

1 Selimi, B., Minority Veto Rights in Kosovo's Democracy, The Age of Human Rights Journal, no. 12, 2019, pp. 148; Korenica, F.; Doli, D., The Politics of Constitutional Design in Divided Societies: The Case of Kosovo, Croatian Yearbook of European Law and Policy, vol. 6, 2010, p. 265.

2 Constitution of the Republic of Kosovo, available at: https://gzk.rks-gov.net/ActDetail.aspx?ActID=3702 (1 June 2021).

3 Ljiphart, A., Democracy in Plural Societies: A Comparative Exploration, Yale University Press, 1977, pp. 25-52. Also, for further explanation see: Kelly, B. B., Power-Sharing and Consociational Theory, Palgrave Macmillan, 2019, pp. 20-38.

4 Carvalho, A. S., Power-sharing: concepts, debates, and gaps, Janus.net e-journal of International Relations, no. 19, https://repositorio.ual.pt/handle/11144/2620 (1 June 2021).

5 Tunheim, J., Rule of Law and the Kosovo Constitution, Minnesota Journal of International Law, vol. 18, no. 2, 2009, pp. 371-379. 
ism. The Constitution of Kosovo, like all constitutions of the region ${ }^{6}$, organizes state power according to the "principle of separation of powers and control of the balance between them'. ${ }^{7}$ Although this is characteristic of presidential and semi-presidential systems, in the case of Kosovo (as, we are sure, in many others), it has been proven that the separation and especially the distribution of power are compatible with parliamentary systems. Democracy and efficient governance in Kosovo have been demonstrably protected by this separation and distribution, and by the supremacy of the legislature, from the tyranny and arbitrariness of government. ${ }^{8}$

Since Kosovo attained its independence in 2008 , the 13 years of this constitutional system have successfully promoted stable, representative, and consociational democracy - but not without challenges. Like any new democracy, democracy in Kosovo has faced political and constitutional crises, the most challenging of which were the elections of the president, the speaker of the assembly, and the prime minister. These challenges seem to have arisen from the interaction of three factors: the proportional electoral system, extreme party pluralism, and the unclear constitutional provisions that govern these offices' election procedures. ${ }^{9}$ While the first two of these factors have so far proved immune to reform efforts, the third has since been improved by the interpretations and construction $s^{10}$ of the Constitutional Court, which have established a stable constitutional practice for electing these authorities. Below, we focus only on the process of forming the government, referring to the processes of electing other authorities only when necessary to explain the former process.

6 See the constitutions of Albania (Art. 6); Croatia (Art. 4); Serbia (Art. 4); Slovenia (Art. 3); Montenegro (Art. 11).

7 Constitution of Kosovo, Art. 4.

8 For more on the impact of power-sharing doctrine, see Albert, R., Presidential values in parliamentary democracies, International Journal of Constitutional Law, vol. 8, no. 2, 2010, pp. 207-236.

9 Shala, Xh., Efekti i sistemit proporcional te sistemi politik dhe formimi i institucioneve të Kosvës, DPhil thesis, European University of Tirana, 2018, p. 155.

10 We join with those who observe the distinction between these two terms as defined by Prof. Solum. See Solum, B. L., Originalism Versus Living Constitutionalism: The Conceptual Structure of the Great Debate, Northwestern University Law Review, vol. 113, no. 6, 2019, pp. 1278-1280. See also Barnett, E. R., Restoring the Lost Constitution: The Presumption of Liberty, updated edition, Princeton University Press, 2004, pp. 118 130; Cisneros, A. L., The Constitutional Interpretation/Construction Distinction: A Useful Fiction, Constitutional Commentary, vol. 27, 2010, pp. 71-92, available at: https:// scholarship.law.umn.edu/concomm/615 (6 June 2021). 
In the first of the following sections, we detail some of the features of Kosovo's parliamentary democracy and contextualize the emergence of political crises. In the second, we present the primary constitutional provisions related to the government-formation process, along with our comments and interpretations (which are independent of the Constitutional Court's). The third section describes and analyzes the judgments (constitutional interpretations and constructions) of the Constitutional Court, as well as the practices for which those judgments serve as a basis. We conclude by arguing that the practice that has emerged from constitutional constructions - since it has already acquired proper legitimacy - should be constitutionalized, be the constitution as rigid as it may. ${ }^{11}$ The interpretations of today may not reflect the interpretations of tomorrow, and for this reason, constitutionalization could serve to prevent new constitutional crises from arising in the future. ${ }^{12}$ We believe that this paper will be a useful resource for further study of comparative constitutional law and the theory of forming parliamentary governments, especially in light of the scarcity of literature that focuses on these subjects in the context of the Balkans. ${ }^{13}$

\section{FEATURES OF PARLIAMENTARY GOVERNMENT IN KOSOVO}

In Kosovo's novel democracy, the process of forming a government is the most challenging of all political and constitutional processes. It is a practical necessity that this be the case because in Kosovo, as in other representative

11 On the rigidity of the Constitution of Kosovo, see Korenica, F.; Doli, D., Constitutional Rigidity in Kosovo: Significance, Outcomes, and Rationale, International Law Review Online Companion, vol. 2, no. 6, 2011, available at: https://digitalcommons. pace.edu/pilronline/22/ (17 June 2021); Ambarkov, N., Constitutional Rigidity in the Countries with Consociational Democratic Approach - A Comparative Perspective, Horizons, vol. 22, 2018, p. 143.

12 Kosovo belongs to the set of countries with a continental legal system. Therefore, while precedent can be useful, it is not binding (and especially not in constitutional justice).

13 We have located regional research performed in Croatia by Prof. Robert Podolnjak and by Prof. Biljana Kostadinov. See Podolnjak, R., Formiranje vlade u Republici Hrvatskoj u komparativnoj perspektivi - jedan prijedlog ustavne promjene, Pravni vjesnik, vol. 34, no. 3-4, 2018, pp. 55-84; Kostadinov, B., Formiranje vlade u razvijenim parlamentarnim demokracijama - SR Njemačka i Velika Britanija, Zbornik Pravnog fakulteta u Zagrebu, vol. 65, no. 6, 2015, pp. 915-930. In Bosnia and Serbia, we located research by Nurko Pobrić and Slaviša Orlović, respectively, but while this research concerns coalition-formation theory, it does not include case studies that can be used for comparison. 
political systems, the process of forming the government is the 'central point' at which all elements of representative policy converge. ${ }^{14}$ Since Kosovo's independence, no election has produced an absolute winner: neither a sole party nor a pre-election coalition has been able to form a government without requiring a new, post-election coalition. In fact, no government has managed to complete a full 4-year parliamentary term. ${ }^{15}$

The impossibility of absolute electoral victory has effectively made post-election coalitions mandatory, and such coalitions have been designed with more concern for the division of posts than for the coordination of policies. This outcome is predictable because in Kosovo, as in most countries in the region, politicians are rather office-seeking rather than policy-seeking. ${ }^{16}$ But predictable or not, it has resulted in governments' lifespans being shortened by opposing political programs and interests. Kosovo is typically governed by a minimal winning coalition ${ }^{17}$, and therefore, the departure of any coalition partner typically results in the loss of majority support and the dissolution of the government. A simple review of the Central Election Commission website reveals that all elections since 2007 occurred early (relative to the theoretically expected 4-year term); it also clarifies that these elections neither empowered new parties nor gave absolute victory to a coalition, thus perpetuating a scenario defined by fragile coalitions. ${ }^{18}$ Yet while Kosovo's governments tend to reign for short periods, the length of time taken to form those governments is similar to that in Western European countries. ${ }^{19}$ On average, government formation in Kosovo

14 Laver, M.; Shepsle, A. K. (eds.), Making and Breaking Governments: Cabinets and Legislatures in Parliamentary Democracies, Cambridge University Press, 1996, p. 4.

15 See Pula, B., Kosovo's Democracy at Risk?, Democracy for Development. Democracy Development Institute Research, available at: https:/d4d-ks.org/en/papers/kosovos-democracy-risk-kosovska-demokratija-pod-rizikom/? (16 July 2021).

16 For more on the typology of political parties, see Müller, W.; Strom, K. (eds.), Policy, Office, or Votes? How Political Parties Make Hard Choices, Cambridge University Press, 1998, pp. 89-108.

17 See the definitions of possible coalitions, Crombez, Ch., Minority Governments, Minimal Winning Coalitions, and Surplus Majorities in Parliamentary Systems, European Journal of Political Research, vol. 29, no. 1, 1996, pp. 1-29.

18 Beha, A.; Baliqi, B., 2014 Elections in Kosovo: A Retrospective, Department of Political Science of the University of Prishtina, September 2014.

19 Daniel, D.; Peter, V. R., The Duration of Cabinet Formation Processes in Western Multi-Party Democracies, British Journal of Political Science, vol. 28, no. 4, 1998, pp. 609-626; Warwick, P., The Durability of Coalition Governments in Parliamentary Democracies, Comparative Political Studies, vol. 11, no. 4, 1979, pp. 465-498. 
takes 92.6 days, situating Kosovo's timeframe within that of states with long government-formation periods but also long-term governments. ${ }^{20}$

Six characteristics beyond these are worth mentioning because they facilitate the understanding not only of the approach of the Constitutional Court but also of our views on the entire process of forming and dismissing a government. We first direct attention to 'parliamentary positivism"21, which is characteristic of some, but not all, parliamentary states. ${ }^{22}$ This refers to the requirement that the candidate nominated for prime minister and the other would-be members of the government must gain the trust of the absolute parliamentary majority, securing what is known as the 'investiture vote'. ${ }^{23}$ Second, we make note of a characteristic rarely encountered in parliamentary systems, and one which speaks to the weakening of the power of the Assembly: the constitutional power of the prime minister to appoint and dismiss members of government. The prime minister requires parliamentary approval only for initial composition of the government cabinet, after which members of the government can be appointed or dismissed without the Assembly's consent. ${ }^{24}$ The third characteristic has two parts. One is that the government cannot under any circumstances dissolve nor propose to the president the dissolution of - parliament; the other is that a successful motion of no confidence is automatically considered a resignation by the government, who therefore are not required to formally resign of their own accord. This common feature is typical of parliamentary democracy. ${ }^{25}$

20 Sejdiu, M., The Political (In)stability and Cabinet Duration in Kosova: Why Are Governments Short-Lived?, Group for Legal and Political Studies Policy Analysis, available at: http://www.legalpoliticalstudies.org/the-political-instability-and-cabinet-duration-in-kosova-why-are-governments-short-lived/ (23 July 2021).

21 For more on positive and negative parliamentarism, see Bergman, T., Formation Rules and Minority Governments, European Journal of Political Research, vol. 23, no. 1, 1993, pp. 55-66; Bergman, T., Constitutional Design and Government Formation: The Expected Consequences of Negative Parliamentarism, Scandinavian Political Studies, vol. 16, no. 4, 1993, pp. 285-304.

22 Examples include Belgium, Denmark, Norway, Sweden, and others. See Rasch, E. B.; Martin, Sh.; Cheibub, J. A., Parliaments and Government Formation, Unpacking Investiture Rules, Oxford University Press, 2015, p. 317.

23 For more on the investiture vote, see Cheibub, J. A.; Martin, Sh.; Rasch, E. R., Investiture Rules and Formation of Minority Governments in European Parliamentary Democracies, Party Politics, vol. 27, no. 2, 2019, available at: https://doi.org/10.1177/ 1354068819850447 (25 July 2021).

24 Constitution of Kosovo, Art. 95 para. 2, Art. 94 para. 4.

25 See e.g. the constitutions of Croatia (Art. 113); Estonia (Art. 92 para. 3); Latvia (Art. 59); Lithuania (Art. 101 para. 2); North Macedonia (Art. 92); Israel (Art. 18); 
The fourth characteristic of note is that the government should, as noted earlier, be representative not only of the parliamentary majority but also of the majority of ethnic communities. ${ }^{26}$ To comply with this constitutional requirement, the composition of the government must follow these rules: if the number of ministries is 12 or fewer, the government must have a Serbian minister and one minister from another non-majority community; ${ }^{27}$ if there are more than 12 ministries, the government must have a third minister from a non-majority community. The fifth feature of Kosovo's democracy is that the Constitution favors the winner of an election not only during the sequence of efforts to form the government ${ }^{28}$ (whether after elections or after dismissal) but also with respect to the makeup of the Assembly. ${ }^{29}$ The Assembly is considered established only once its chair has been elected, and it is the right of the winner of the election, 'the largest parliamentary group', to nominate a candidate for chair. ${ }^{30}$ Regarding

all available at: Elkins, Z.; Ginsburg, T.; Melton, J., Constitute: The World's Constitutions to Read, Search, and Compare, Constitute Project, www.constituteproject.org (28 July 2021).

26 Constitution of Kosovo, Arts. 64, 96. This is a rare feature; it can be found in the constitution of Bosnia and Herzegovina, which defines the multiethnic composition of representatives of the Collective Presidency and the House of Peoples. For details, see also the Constitution of the Federation of Bosnia and Herzegovina, https://www.paragraf.ba/propisi/bih/ustav-bosne-i-hercegovine.html (28 July 2021). See also the Constitution of Belgium, Art. 99, where an arguably similar requirement of equal numbers of Dutch- and French-speaking ministers appears. Lebanon is another example, but only regarding the proportional parliamentary representation of religions, sects, and regions; see also the Constitution of Lebanon, Arts. $24-26$.

27 Other constitutionally recognised ethnic groups that should be represented in the government and Assembly are the Bosnian, Turkish, Roma, Egyption, Ashkali, and Gorani communities.

28 These features can also be found in other parliamentary democracies, including Albania, Greece, Bulgaria, North Macedonia, and others.

29 In most of the parliamentary republics with which we have drawn comparisons, the procedure for electing the speaker of parliament is a matter of standing orders and not, as it is in Kosovo, a constitutional issue. In some countries (Serbia, Macedonia, Montenegro, Estonia, Lithuania, Latvia, and others), some of these standing orders create opportunities for more candidates to compete.

30 See Judgment in Constitutional Review of Decision No. 05-V-001 voted by 83 Deputies of the Assembly of the Republic of Kosovo on the election of the President of the Assembly of the Republic of Kosovo (2014) No. KO119/14 (Constitutional Court of Kosovo), paras. 116-118, https://gjk-ks.org/wp-content/uploads/vendimet/gjk_ko_119_14_ang.pdf (18 September 2021). According to the Constitution of Kosovo (Art. 67 para. 2), the speaker of the Assembly is nominated by the 'largest parliamentary group'. 
the prioritization of the election-winner in the formation of the government, the particularity lies in the fact that this deference is guaranteed by the Constitution and then clarified by the Constitutional Court, whose judgments eliminated the dilemmas produced by past political crises (a subject of discussion further below). In other cases, constitutional practice, as well as studies of the government-formation process ${ }^{31}$, generally supports the relative winner (that is, the plurality), but when it is impossible to form a coalition with a sufficient majority, it is possible to form other majorities, even with those parties that have won the least seats, if such a majority would result in a post-election coalition. Sixth and finally, Kosovo is among those states whose processes for forming and dismissing the government are regulated by the constitution and by parliamentary rules. However, the uncertainty and ambiguity of legal norms - especially constitutional provisions - has brought to the forefront the insufficiency of the constitution in this regard. As a result, political and constitutional crises have emerged, explicitly concerning the formation of governments.

The first challenge emerged in 2011, three years after Kosovo's declaration of independence and the entry into force of its constitution. Following the 2011 elections, a coalition agreement between $\mathrm{H}$. Thaqi and B. Pacolli ${ }^{32}$ specified that the former would assume the office of prime minister and the latter the presidency. ${ }^{33}$ However, the newly elected Assembly failed to elect a new president when it could not achieve a quorum - the result of a boycott by opposition parties. The crisis was eventually resolved: the constructive behavior of the AKR (AKR (New Kosovo Alliance) leader permitted the coalition to survive for some time, and, with the mediation of the U.S. Embassy, to reach a consensus with

This group is supposed to belong to the party or coalition that has won the largest number of votes and, correspondingly, seats in the Assembly. Thus, majorities that can be created regardless of the relative winner of the election are not to be considered. The Constitutional Court has clarified that the 'largest parliamentary group' should be considered the party, coalition, civic initiatives, and independent candidates who have 'more seats' in the Assembly on the day of the constitution of the Assembly.

31 Fujiwara, Th.; Sanz, C., Rank Effects in Bargaining: Evidence from Government Formation, The Review of Economic Studies, vol. 87, no. 3, 2020, pp. 1261-1295; Cyr, H., On the Formation of Government, Review of Constitutional Studies, vol. 22, no. 1, 2017, pp. 103-141.

32 Thaqi and Pacolli led the Kosovo Democratic Party and New Kosovo Alliance, respectively.

33 The Agreement Between PDK and AKR is Signed, Ekonomia (19 February 2021), http:// www.ekonomia-ks.com/sq/politike/nenshkruhet-marreveshja-mes-pdk-se-dhe-akr-se (20 August 2021). 
the then-largest opposition party, LDK (Democratic League of Kosovo), for the election of A. Jahjaga as President non-partisan. ${ }^{34}$

Another crisis arose after the early elections of 2014, which, like all other election cycles, did not result in an absolute winner. This particularly challenging crisis, which resulted in six months of political paralysis before a new government was formed, developed when the parliamentary parties of the Albanian ethnic majority unanimously refused to join any coalition with the winning party, PDK (Kosovo Democratic Party). Despite the eventual support of all MPs from non-majority communities, PDK was unable to secure the absolute majority necessary to form a government. The post-election coalitions of the opposition parties, arguing that they could together achieve a majority of seats, sought to constitute the Assembly and form a government, but these efforts, lacking the participation of the winning party, were deemed unconstitutional by the Constitutional Court. As we discuss below, this political crisis gave the Constitutional Court a powerful opportunity, through its interpretations and constructions, to establish the current constitutional practice of electing the government. This practice would be challenged in 2020, when the LVV (Self-determination Movement) - LDK coalition was dissolved and, at the request of LDK, a no-confidence vote removed the Kurti government from office. The resultant situation again raised doubts and questions: should the Assembly necessarily be dissolved after the discharge of the government? If not, who should form the new government?

Now, having explored the nature of the past crises and the most relevant features of Kosovar parliamentarism, we can more easily understand and explain the constructed constitutional practice of forming a government, which is based on the interpretation of the Constitutional Court. But before analyzing this practice, it is necessary to present the constitutional provisions that are pivotal in the process of forming and dismissing the government. We do so below, followed by our own doctrinal interpretation, and finally, we examine the final interpretations and constructions of the Constitutional Court itself.

34 See the Kosovo Government's announcement on the subject: https://kryeministri. rks-gov.net/en/prime-minister-thaci-we-the-three-leaders-of-our-parties-pdk-ldkand-akr-have-reached-an-agreement-for-a-reformed-kosovo-a-european-kosovo/ (13 August 2021). 


\section{CONSTITUTIONAL PROVISIONS FOR THE FORMATION OF THE GOVERNMENT AND THEIR POSSIBLE INTERPRETATIONS}

Although it is difficult to find two countries in which the procedure is truly identical - especially when it comes to the finer details - the process of forming a government is similar in most democracies. ${ }^{35}$ Features typical of most cases can be drawn on to create a generic model that begins with a candidate's nomination and ends with a vote of confidence (or investiture vote). As noted above, the process of forming a government in Kosovo is defined by constitutional provisions, which provide for and regulate the three primary scenarios in which the government-formation process is triggered. The first scenario arises after parliamentary elections; ${ }^{36}$ the second may unfold after a vote of no confidence is passed against the government and no vote of confidence (for the government) is requested by the prime minister. ${ }^{37}$ The third situation takes place if the post of prime minister remains vacant, either because the prior officeholder has resigned; because of the absence of a completed vote on the motion of confidence requested by the Prime Minister; or because of 'other reason[s]' - which may become matters of interpretation as the Constitution does not specify them. ${ }^{38}$

The Constitution has three provisions regarding the forming a government after elections. Chief among them is Article $95^{39}$, which is wholly devoted to the

35 For relevant data and comparisons, see Podolnjak, R., op. cit. (fn. 13).

36 Constitution of Kosovo, Art. 84 paras. 14, 95.

37 Ibid., Art. 100 paras. 1-2.

38 Ibid., Art. 95 para. 5.

39 Ibid., paras. 1-5. '1. After elections, the President of the Republic of Kosovo proposes to the Assembly a candidate for Prime Minister, in consultation with the political party or coalition that has won the majority in the Assembly necessary to establish the Government. 2. The candidate for Prime Minister, not later than fifteen (15) days from appointment, presents the composition of the Government to the Assembly and asks for Assembly approval. 3. The Government is considered elected when it receives the majority vote of all deputies of the Assembly of Kosovo. 4. If the proposed composition of the Government does not receive the necessary majority of votes, the President of the Republic of Kosovo appoints another candidate with the same procedure within ten (10) days. If the Government is not elected for the second time, the President of the Republic of Kosovo announces elections, which shall be held not later than forty (40) days from the date of announcement. 5. If the Prime Minister resigns or for any other reason the post becomes vacant, the Government ceases and the President of the Republic of Kosovo appoints a new candidate in consultation with the majority party or coalition that has won the majority in the Assembly to establish the Government.' 
post-election forming of a government. Second is a specific paragraph within Article 84, which lists the constitutional powers of the president; therein, paragraph 14 includes among these competencies the appointment of the candidate for prime minister. The third provision (Article 82, para. 1) ${ }^{40}$ concerns the dissolution of the Assembly, authorizing the president to take such a step if a government is not elected within 60 days of the first candidate's nomination for Prime Minister. Article 95 provides that 'after the elections, the President proposes to the Assembly the candidate for Prime Minister, in consultation with the political party or coalition that has won the necessary majority in the Assembly to form the Government'. Article 84 also contains, as one of the 30 powers it explicitly defines, the president's authorization to 'appoint the mandator for the formation of the Government, upon the proposal of the political party or coalition, which constitutes the majority of the Assembly'. In contrast, in situations when the prime minister resigns, or when the position remains vacant for other reasons, Article 95 (para. 5) stipulates that '... the President of the Republic of Kosovo, in consultation with the political party or coalition that has won the majority in the Assembly, mandates the new candidate to form the Government.'

In addition to the Constitution, the Rules of Procedure of the Assembly also regulate the process of forming the government. The Rules mostly reiterate the constitutional provisions in question, and they do so only in terms of the forming a government after elections. However, we note that the provisions of the Rules are clearer, especially with respect to the procedure for nominating a prime minister after elections. ${ }^{41}$ Whereas the Constitution requires the president to nominate a candidate from the party or coalition that has won the majority needed to form the government after the parliamentary elections, the Rules require the president's nominee rather to be from the party or coalition that has won the majority of seats in the Assembly, in relation to other parliamentary parties or coalitions. The difference is clear: the constitutional requirement implies an absolute majority of 61 deputies $^{42}$, whereas the requirement of the Rules of Procedure implies a plurality, or relative majority.

Following from this latter reasoning, and distinct from previous interpretations, it could be justified by a constitutional construction that the winner of the

40 Ibid., Art. 82 para. 1. 'The Assembly may be dissolved by the President of the Republic of Kosovo following a successful vote of no confidence against the Government.'

41 Rules of Procedure of the Kosovo Assembly 2010, Arts. 29-31, https://www.assembly-kosova.org/Uploads/Data/Files/6/Rr_K_RK_29_04_2010_1_EDbu8aqXYd.pdf (8 September 2021).

42 The Assembly has 120 members, so an absolute majority requires 61 . 
elections - even if it received just one vote more than each individual competing party - has the right to propose the candidate for prime minister. This construction can be supported by principled democratic reasoning: democratic elections deal with the competition of political programs, and accordingly, the program that receives the most votes should be favored for implementation. Even when the other parties, together, can form an absolute majority, this majority does not give the corresponding coalition sufficient democratic legitimacy to seize priority in the formation of the government because the coalition represents a new, mixed political program that was unknown to the electorate during the elections and therefore not voted on. So, despite the words 'majority needed to form the government' or 'majority of the Assembly', a new constitutional construction of this nature would award the sole winner of the election the right to nominate a candidate for the government (or indeed to form a government). Parties and pre-election coalitions would be compelled to earn the most votes, and only then to partner with other parliamentary parties.

The Constitution is silent on the deadline by which the president must nominate a candidate for prime minister, which leaves political parties and the president indefinite time to engage in political negotiation or consultation for the purpose of producing a candidate with absolute parliamentary support. However, deadlines do come into play after the president has made this nomination; four different deadlines may apply, each with its own consequences. The first marks the end of the 15-day period within which the first nominee for prime minister must describe the composition of the government and seek parliamentary confidence in it. If the candidate for Prime Minister fails to propose the government's composition to the Assembly by this deadline, or if the proposed composition does not receive the votes of an absolute majority (61 deputies), then the candidate cannot be nominated again. The second deadline applies if the first attempt to form a government fails, after which the president has 10 days to nominate another candidate for prime minister according to the 'same procedure'. ${ }^{43}$ After nomination, the second nominee has 15 days in which to nominate a cabinet and receive the parliamentary vote of confidence. If a cabinet is not proposed and invested by this third deadline, the president must declare free elections, which must be held no later than 40 days after their announcement (the fourth deadline).

All of the above possible political developments must take place within a general deadline of 60 days of the nomination of the first candidate for prime minister. As for more unusual situations, such as when the prime minister resigns

43 Constitution of Kosovo, Art. 95 para. 4. 
or when, for whatever reason, the post of prime minister remains vacant, the Constitution authorizes the president, in 'consultation with the party or coalition that has won the majority in the Assembly', to nominate another candidate for prime minister. In these situations, the Constitution sets no deadlines or indeed any conditions at all for the selection, except that the candidate must be identified in consultation with the victorious party or coalition. Also, in the event that a vote of no confidence is passed against the government, mutatis mutandis, the Constitution allows the president to dissolve parliament. ${ }^{44}$

At this point, anyone with basic knowledge of constitutional interpretation can draw a variety of conclusions from the provisions (as they are detailed above) set forth in the Constitution; even when we set out to define the same processes, sharing one goal, each of us might articulate those processes differently in words. The most vexing dilemmas arise in determining which political entity has the right to nominate a candidate for prime minister, or in other words, who should be considered the winner of the election. As we have seen above, the Constitution alternatingly considers the winner to be the political entity (party or coalition) that has the "necessary majority in the Assembly to form the government ${ }^{45}$, the political entity that has won the "majority of the Assembly"46, and, when forming a new government with the same legislature, the party or coalition that has the 'majority in the Assembly'. In the first case, one could say that majority cannot realistically be attained through a vote of the people, given the characteristics of the electoral system and the extreme party pluralism that characterizes Kosovar elections. Accordingly, the President should, in this case, consider the winner to be any entity, even a post-election coalition, that achieves this majority and should nominate a candidate for prime minister in consultation with that entity. In the second case, the situation may grow even more unclear. The provision authorizing the president to nominate a candidate also dictates the candidate's selection; only candidates proposed by the party or coalition that has a 'majority in the Assembly'47 may be nominated. Thus, a possible interpretation might be as follows: the president should await a proposal from the winner - that is, the entity that has managed to negotiate a majority coalition - and only then should appoint the prime minister. It is logical, albeit rather creative, to believe that the Constitution provides for a candidate's initial

44 Constitution of Kosovo, Art. 82 para. 1.

45 Ibid., Art. 91 para. 1.

46 Ibid., Art. 84 para. 14.

47 In the English and Serbian versions of the Constitution, this portion was translated as 'the majority in the Assembly', and 'većina u Skupštini', respectively. A proper translation should read, 'majority of Assembly'. 
approval in the Assembly by a majority-achieving post-election coalition and subsequent appointment by the President. ${ }^{48}$ Another interpretation, and one perhaps more thought-provoking for interpretational doctrine, is also possible: the determination of the meaning of the constitutional provision that prescribes solutions in case the first attempt to establish a government within 15 days fails. The provision holds that in such cases, '... the president, within 10 days, nominates another candidate, according to the same procedure'. ${ }^{49}$ Here, the quandary concerns the length of the period allotted to the second nominee for the purpose of forming the government and seeking the trust of the Assembly. The phrase 'according to the same procedure' tells us the procedure leading up to the proposal, but it does not convey a deadline. With no deadline specified, it is logical to say that the second candidate has only the time remaining before the overall deadline of 60 days since the first candidate's nomination, before which a government must be elected, lest the Assembly be dissolved. While this interpretation seems reasonable, it amounts to another 15 days from the nomination of second candidate, which took place within 10 days of the failure of the first candidate. Next, the expression 'according to the same procedure' can be interpreted as a procedure in which the president, in consultation with the same party or coalition as in the first attempt, proposes another candidate for prime minister.

Clearly, the formulation of these constitutional provisions is broad and indefinite - thence the 'apple of discord' and, moreover, the inimical cases of political deadlock that have affected the country, as they did in 2014 and 2020. Even more potent challenges will arise if a motion of no confidence is passed against the prime minister, or if the post of prime minister is resigned or left vacant for 'other reasons. ${ }^{50}$ What these other reasons might be, has not been determined, remaining yet a matter of interpretation. These interpretations vary according to the context in which the situation may arise. Consider, for comparison's sake, the constitutional provision that authorizes the president to dissolve the parliament after a motion of no confidence is passed against the prime minister. Does it entitle the president to dissolve parliament according

48 This interpretation was held by one of the judges in his dissenting opinion in this case. See Constitutional Court of the Republic of Kosovo, Applicant The President of the Republic of Kosovo Concerning the assessment of the compatibility of Article 84, paragraph 14, with Article 95 of the Constitution of the Republic of Kosovo, Dissenting Opinion of Judge Robert Carolan in Case No KO103/14, https://gjk-ks.org/wp-content/uploads/ vendimet/gjkk_ko_103_14_mm_shq.pdf (8 September 2021).

49 Constitution of Kosovo, Art. 95 para. 4.

50 Ibid., para. 5. 
to his or her discretion, or does it oblige the president to do so? No other provision speaks to the situation, and consequently, the proper way to proceed is simply not known. The situation is distinct from a scenario in which the prime minister resigns or when 'for other reasons his post remains vacant' as in these latter cases, the Constitution explicitly prescribes the president's nomination of a new candidate 'in consultation with the political parties or the coalition that has won the majority in the Assembly'. ${ }^{51}$

Setting aside this question, we return once more to the dilemma of whether the majority required to form a government can be achieved after an election or must be earned beforehand (and to the differing interpretations of the issue that we have explored above). One logical interpretation would be to give preference to the largest parliamentary groups created after the parliamentary elections, as there is now an established Assembly and deputies have a free mandate. In other words, if deputies are required to play for the political team with which they entered the race until the Assembly is established, they are free to act as individuals after the Assembly's establishment. Equally logical and consistent with the initial procedure is the interpretation that the party with the relative majority in the Assembly still retains priority. The expression 'for other reasons, his or her post remains vacant' may also cover the situation in which the post remains unfilled because of a vote of no confidence in the prime minister and hence would apply to the provision relating to the resignation. Again, it can be clearly seen that the Constitution's provisions on the subject could be indefinite, allowing for numerous possible interpretations and therefore representing a source of political and constitutional crises. In such crises in the past, the Constitutional Court of Kosovo has played a crucial role in establishing the constitutional practice of forming a government, which is now considered legitimate in Kosovo's consolidated democracy. We agree with those who consider the judgments and interpretations of the Constitutional Court regarding the government, president, and Assembly to be decisions that have matured Kosovo's politics and contributed to the maintenance and consolidation of its parliamentary democracy, as well as the 'consolidation of constitutional identity ${ }^{\prime 52}$ - especially the decisions regarding the election

51 Ibid.

52 Hasani, E., Judicial Review of Democracy. Maintenance of Democracy as a Functionalist Mission in the Jurisprudence of the Constitutional Court of Kosovo, Comparative Southeast European Studies, vol. 68, no. 4, 2020, pp. 530-553; Gërxhaliu, S., Democracy as a Constitutional Value and its Mainstreaming in Court Cases, XXII International Congress on European and Comparative Constitutional Law, Vilnius, October 2019, available at: https://www.lrkt.lt/data/public/uploads/2020/10/the-concept-of-democracy-web. 
of the president. ${ }^{53}$ Moreover, in support of this constructed constitutional practice, and in light of all the ambiguities that remain, we consider necessary the constitutionalization of the current practice by way of a constitutional amendment. Without it, the current practice cannot take root as it will be threatened by new and different interpretations, which we show above to be both possible and defensible.

In the next section, we observe how the Constitutional Court has judged and interpreted the constitutional provisions that define and regulate the process of electing the government in two situations: after parliamentary elections, and after the dismissal of the government.

\section{INTERPRETATIONS OF THE CONSTITUTIONAL COURT AND THE CONSTITUTIONAL PRACTICE OF FORMING THE GOVERNMENT}

2014 and 2019, both electoral years with early parliamentary elections, brought unprecedented political challenges, but they also presented opportunities for new democratic developments. Foremost among these opportunities were advances in constitutional law. The affairs of 2014 yielded a clear definition of the process of forming a government after elections, and the crisis in 2019 resulted not only in the reinforcement of that definition but also in a new definition, this one of the government-formation process after a preceding government is dismissed. These developments, both great challenges, can be summarized and analyzed as a three-act drama: both the 'setting' (the constitutional provisions) and the 'actors' (political and institutional entities) are the same, and each crisis has a coherent resolution.

pdf (16 September 2021); Korenica, F.; Doli, D.; Rexha, A., Promising Early Years: The Transformative Role of the Constitutional Court of Kosovo, Analitika - Center for Social Research Working Paper 4 , 2016, http://www.legalpoliticalstudies.org/wp-content/ uploads/2016/09/Final-September-2016-Constitutional-Court-Kosovo-WP-1.pdf (16 September 2021).

53 Regarding the decisions of the Constitutional Court on the election of the president, see Qerimi, Q.; Qorolli, V., A Constitutional Tradition in the Making: The Presidents' Cases and the Role of Kosovo's Constitutional Court in the Process of Democratic Consolidation, Journal on International Constitutional Law, vol. 7, no. 1, 2013, pp. 49-57. We consider that even today, there is debate between academics regarding the quorum for holding the vote on the election of the president; it is not clear whether everyone, excepting those who are absent with permission, should be $2 / 3$ during the first two votes or even the third. 
The prelude to the first drama was the early parliamentary elections of June 8,2014 , which, like all prior elections, did not produce an absolute winner. The party that received the most votes, PDK, failed to find coalition partners; all of the losing parliamentary parties (LDK, AAK, NISMA, and VV) had decided to form a coalition, VLAN, and create a new majority. ${ }^{54}$ This post-election coalition insisted it had a 'majority'55 that entitled it to both form a government and elect the speaker of the assembly, creating a political stalemate in which both of these 'highly vexing questions' had to be answered. ${ }^{56}$ The post-election coalition parties began by attempting to elect the speaker of parliament, whose election is considered a constitutive moment in concluding the process of Assembly's establishment. As such, the election of the speaker confers the legitimacy to then form the government. PDK's attempts to elect the speaker had failed, and the new coalition managed - though violating the procedures and practices of the period - to do so, having formed a new majority and ostensibly becoming the 'authorized parliamentary group' capable nominating a candidate for speaker of the assembly. ${ }^{57}$

The battle, then, was over which parliamentary group was truly authorized to nominate a candidate for speaker: the largest parliamentary group that emerged directly from the election results, or the new parliamentary group created as a post-election coalition. The Constitution and the Rules of Procedure of the Assembly were clear that the nomination should be made by the 'largest parliamentary group' but did not specify anything about the time at which the 'largest' group was created. PDK, having won in terms of raw votes, challenged the coalition in the Constitutional Court, insisting that constitutional procedures were violated during the election of the president of the Assembly. ${ }^{58}$ The primary bases of the coalition's argument ${ }^{59}$ were the constitutional provisions according to which ' $[\mathrm{t}] \mathrm{he}$ seats in the Assembly are distributed amongst all parties, coalitions, citizens' initiatives and independent candidates in proportion to

54 Hasani, E., The Role of the Constitutional Court in the Development of the Rule of Law in Kosovo, Review of Central and East European Law, vol. 43, no. 3, 2018, pp. 274-313.

55 VLAN, Jahjagës: Ne jemi shumica, ne jemi zgjidhja e menjëhershme, Telegrafi.com (18 September 2014), https://telegrafi.com/vlan-jahjages-ne-jemi-shumica-ne-jemi-zgjidhjae-menjehershme/ (17 September 2021); Muhaxheri, A., "Bulldozeri” në Kuvend, The Albanian (4 October 2014), https://www.thealbanian.co.uk/buldozeri-ne-kuvend/ (17 September 2021).

56 See Korenica et al., op. cit. (fn. 52).

57 Shala, op. cit. (fn. 9), pp. 180, 188.

58 Xhavit Haliti (Case No KO119/14), op. cit. (fn. 30).

59 Ibid., paras. $42-43$. 
the number of valid votes received by them in the election to the Assembly ${ }^{160}$, and the 'President of the Assembly is proposed by the largest parliamentary group and is elected by a majority vote of all members of the Assembly'. ${ }^{61}$ Representatives of the so-called new parliamentary group, formed after the election, insisted that they were the largest parliamentary group and therefore able to legitimately nominate a candidate, despite being a parliamentary group leaving the post-election coalition. The applicants claimed that '.. the largest "parliamentary group" is not determined by the political party or coalition, but by the free will of the Deputies to join either based on political affiliation or based on program as stipulated in the Rules of Procedure of the Assembly'. ${ }^{62}$ The Constitutional Court handled the case with great efficiency ${ }^{63}$, initially taking interim measures by suspending the decision on the election of the president of the assembly ${ }^{64}$ and later issuing a judgment declaring unconstitutional and nullifying the election of the president of the assembly 'as regards the procedure followed, and as well as in substance, as it was not the largest parliamentary group that made the proposal. ${ }^{65}$

With this decision, which draws to a close the first act of this 'political drama', the advantage - even if merely a relative one - of the election-winner was preserved in the process of proposing a candidate for president of the assembly without interfering in the political and democratic processes of the candidate's own election. In other words, a candidate can also be a deputy of any other parliamentary party, but he or she should be nominated by the party or coalition that has received the most votes from the electorate.

The second act took place in the same period and featured the same political actors. In fact, for the Constitutional Court, this could arguably be considered its first act - and certainly one of its more efficient ${ }^{66}$ trials. ${ }^{67}$ This phenomenon

60 Constitution of Kosovo, Art. 64 para. 1.

${ }_{61}$ Ibid., Art. 67 para. 2.

62 Judgment in Case No KO119/14, op. cit. (fn. 30), para. 53.

63 The application was submited 18 July 2014, the decision for interim measures issued 23 July 2014, and the final judgment issued 26 August 2014.

64 Decision on Interim Measure III in Case No KO119/14 (fn. 30) dated 17 July 2014, https://gjk-ks.org/wp-content/uploads/vendimet/KOl19-14_VMP_ANG.pdf (19 September 2021).

65 Judgment in Case No. KO119/14, op. cit. (fn. 30), para. 43.

66 The application was submitted 19 August 2014 and the decision of the Court issued 1 July 2014.

67 Constitutional Court of the Republic of Kosovo, Applicant the President of the Republic of Kosovo Concerning the assessment of the compatibility of Article 84 (14) [Competencies of 
was not new; it had occurred, and indeed continues to occur, as a consequence of the political system. The new development, rather, was the boycott of the winning party, which saw opposition parties refuse to join a coalition to form the majority of the Assembly, or 'the majority needed in the Assembly to form the Government'. ${ }^{6}$ The president, faced with ambiguous constitutional provisions but retaining the duty to nominate a candidate for prime minister, addressed the Constitutional Court and requested an interpretation.

The president, inter alia, sought the interpretation of the term 'majority' in all possible contexts mentioned above, including the clarification of pre- and post-election coalitions; the Court's interpretation of a hypothetical situation in which the first candidate nominated failed to receive the Assembly's confidence; and the determination of the priority of different constitutional provisions (namely Article 84 para. 14 and Article 95 para. 1) governing the same political process. ${ }^{69}$ The Constitutional Court, based on constitutional and democratic principles and values, but also on the experiences of similar parliamentary states, answered each question raised by the president.

On the issue of political parties vs. coalitions in the context of the procedure for forming the government after the elections, the Court concluded that the party or coalition legitimately entitled to nominate a candidate for prime minister would be, for the first time, one created before the parliamentary elections. ${ }^{70}$

On the second issue - which concerns the 'majority' required to propose a candidate for prime minister to the president - the Court specified that a legitimate majority for the purposes of such proposal belongs to a '... party or coalition that has the majority of the seats in the Assembly, be it absolute or relative.'. ${ }^{71}$ According to the Court, '[t]he government stems from the prevailing political power within the parliament and is rooted into the political force that wins the elections. This can be an absolute or relative win'. ${ }^{72}$ As a result of the Court's decision, the president was for the first time fully dependent on this proposal, enjoying no discretion at all to nominate a candidate without

the President] with Article 95 [Election of the Government] of the Constitution of the Republic of Kosovo (2014), Judgment in Case No K0103/14 of 1 July 2014, https://gjk-ks. org/wp-content/uploads/vendimet/gjkk_ko_103_14_ang.pdf (19.09.2021) (Case No K0103/14).

Constitution of Kosovo, Art. 14 para. 4, Art. 95 para. 1.

Judgment in Case No 103/14 (fn. 67), paras. 2, 3, 47.

Ibid., 23, final decision, subpara. b.

Ibid., 23, final decision, subpara. c.

Ibid., para. 49. 
deference to the election-winner's selection. The Court further held that in the case that the first candidate should fail, full discretion belonged the candidate's nominee, who could hail from the same party or coalition or even from any other parliamentary party or coalition. ${ }^{73}$ As is characteristic of some other states ${ }^{74}$, the Court left no room for minority governments but rather awarded priority to the majority, which can be created in spite of ideological differences. As for the quandary raised by the president - the possible collision of the provisions for the formation of the government - the Court found no contradictions; on the contrary, it described the provisions as compatible. ${ }^{75}$

These interpretations allowed the realization of powers and deadlines explicitly provided for in the Constitution. One example is the president's discretion to nominate a candidate for prime minister from another party or parliamentary coalition after the failing to produce an acceptable first candidate. The wording 'according to the same procedure', interpreted from the standpoint of '.. . the letter and spirit of the constitution and the principles of democracy and democratic governance', served as the basis by which this competency was finally defined with rigor. ${ }^{76}$ The same can be said for the construction of the party or coalition's 'relative majority' necessary for the nomination of a prime ministerial, which the Court understood was '... applied in jurisprudence and constitutional practice and must be in accordance with constitutional principles in a democratic society .... ${ }^{77}$

In light of this, the general formulations on which the Constitutional Court's conclusions were based seem readily apparent. Accordingly, we consider that these conclusions exemplify constitutional construction, rather than constitutional interpretation ${ }^{78}$, and as such were capable of establishing solid

73 Ibid., paras. e, f, g.

74 The German process of government-formation is a possible example; see Kostadinov, op. cit. (fn. 13), pp. 915-930.

75 Judgment in Case No 103/14 (fn. 67), final decision, subpara. a.

76 Ibid., para. 58.

77 Ibid., para. 75

78 According to Lawrence Solum, 'constitutional interpretation' is the activity that discerns the communicative content (linguistic meaning) of the constitutional text, whereas 'constitutional construction' is the activity that determines the content of constitutional doctrine and the legal effect of the constitutional text. See Solum, B. L., Originalism and Constitutional Construction, Georgetown Law Faculty Publications and Other Works, vol. 28, 2013, pp. 451-457. 
government-formation practices. The Court's judgment was criticized ${ }^{79}$, but it was not challenged until 2020, when political deadlock arose once more. This third and final act of our political drama took shape after the parliamentary elections of October 6, 2019, which again, unsurprisingly, produced not absolute winners but relative ones - in this case the party Lëvizja VETËVENDOSJE! (LVV), a first-time winner. ${ }^{80}$ By this point, it was clear that the winner of any majority, absolute or relative, had the right to nominate the first candidate for prime minister, but also that the support of the parliamentary majority had to be secured a priori. After about five months of negotiations, a coalition led by the victorious LVV was formed, with the Democratic League of Kosovo (LDK) - which had just one fewer $\mathrm{MP}^{81}$ - joining as the second party.

This ill-fated coalition did not even reach the usual 100 days of government. Ideological differences, distinct approaches to foreign as well as domestic policy (especially in relation to managing the developing COVID-19 situation), and political stubbornness and rigidity conspired to bring about the government's dissolution after just 52 days in power. The fatal motion of no confidence ${ }^{82}$

79 GjK $u$ hap derën spekulimeve: Dy Versionet për mandatarin e ardhshëm [The Constitutional Court Opened the Door to Speculations: Two Versions for the New Successor], Telegrafi.com (30 Jun 2014), https://telegrafi.com/gjk-u-hap-deren-spekulimeve-dyversionet-per-mandatarin-e-ardhshem/ (23 September 2021); Gashi, Z., Pas PDK-së, mandatari i qeverisë nga cilado parti [After PDK, the Successor of the Government Can Be from Whatever Party], Radio Free Europe (2 July 2014), https://www.evropaelire.org/a/25442706.html (23 September 2021).

80 Lëvizja VETËVENDOSJE! was the first political party to hold 29 parliamentary seats. It was closely tailed by the Democratic League of Kosovo, which held just one fewer seat; third and fourth were the Democratic Party of Kosovo and Alliance for the Future of Kosovo, respectively. The other political parties, which respresented minority ethnic communities, together constituted the 20 seats remaining of the total 120 in the Assembly. See Central Election Comision of Kosovo, https:// www.kqz-ks.org/wp-content/uploads/2019/11/3.Ndarja-e-ul\%C3\%ABseve-n\%C3\%AB-Kuvend-Subjektet-dhe-kandidat\%C3\%ABt-e-zgjedhur-1.pdf (23 September 2021).

81 Kosovo Parties Sign Agreement on Coalition Government Led by Albin Kurti, Exit News (20 February 2020), https://exit.al/en/2020/02/02/kosovo-parties-sign-agreement-on-coalition-government-led-by-albin-kurti/ (24 September 2021); Krasniqi-Veseli, L.; Sadiku, M., Nënshkruhet marrëveshja për koalicionin qeverisës, Radio Evropa e Lirë (2 February 2019), https://www.evropaelire.org/a/lvv-ldk-marreveshje-koalicion-/ 30411933.html (24 September 2021).

82 Ky është teksti i mocionit të mosbesimit ndaj Qeverisë Kurti i përgatitur nga LDK-ja (Document), Evropa e Lire (3 February 2020), https://www.evropaelire.org/a/30508373. html (24 September 2021). 
was in fact introduced by the coalition partner, LDK; it was affirmed by the votes of 82 deputies. ${ }^{83}$ After social and political dispute, the majority of the parliamentary parties expressed their will to form a new government with the incumbent legislature. The president therefore immediately began the procedure for proposing a new candidate for prime minister, who was selected from the originally triumphant party, LVV. This was the onset of the second test of the constitutional design and doctrine of the government-formation process after completed elections, this time with the unique element of forming a government after a motion of no confidence. Neither the Constitution nor the Rules of Procedure of the Assembly prescribed guidance as to how to handle such a scenario. Only two articles (Article 100 para. 6 and Article 82 para. 2) dealt with the subject; according to these, 'after the motion of no confidence the government is considered to resign', and in these cases, 'the President can dissolve the Assembly' ${ }^{84}$

The president, in fulfilling the office's capacity as guarantor of the democratic functioning of institutions and the authority governing the process of nominating the candidate for prime minister, sought the name of a candidate from LVV. Subsequently, in consultation with all other parliamentary parties and in accordance with their will, the president decided to nominate a candidate proposed by LDK (the second member of the original coalition), which had found the support of the parliamentary majority. ${ }^{85}$ The first party, petitioned the Constitutional Court, claiming that the president had violated the Constitution because, they argued, the president was required to dissolve the Assembly and initiate new parliamentary elections after a vote of no confidence was passed. Such dissolution is required because there are no other constitutional provisions that specify proper conduct after a vote of no confidence in the government has passed. ${ }^{86}$ And in any case, because the Assembly had not been dissolved, the president should have identified a new candidate only in consultation with LVV, as the winning party.

83 Bie Qeveria Kurti, Epoka e Re (25 March 2020), https://www.epokaere.com/bie-qeveria-kurti/ (24 September 2021).

84 Emphasis added; Constitution of Kosovo, Art. 100 para. 6, Art. 82 para. 2.

85 Constitutional Court of the Republic of Kosovo, Applicant Rexhep Selimi and 29 other deputies of the Assembly of the Republic of Kosovo Constitutional review of Decree No. 24/2020 of the President of the Republic of Kosovo of 30 April 2020, Judgment in Case No KO72/20 of 1 June 2020, paras 95, 105, https://gjk-ks.org/wp-content/ uploads/2020/06/ko_72_20_agj_ang.pdf (25 September 2021).

86 Ibid., paras. 337, 416. 
It is interesting to note that both the president and the representatives of the winning party - the petitioner of the Court - based their comments on the pivotal judgment in Case KO 103/14, which we analyzed above. The case was decisive for the practice of the government-formation process after an election, but it made no comments about the new situation that the president and Assembly found themselves in after a successful motion of no confidence. The president acted on the premise that this new situation was analogous, politically, and constitutionally, to post-election conditions in which the winning party relinquishes the nomination of its candidate or fails to gain the trust of the parliamentary majority. ${ }^{87}$

When the Constitutional Court ruled, it based its decision on a comparative analysis, the opinions of the Venice Commission, and the preparatory documents for the drafting of the Constitution. ${ }^{88}$ The court held that the process of proposing and forming a new government, with same legislature and with a second party (in this case, LDK) candidate was constitutional. In the Court's view, the constitutional provisions concerning situations in which the prime minister resigns should also apply to situations in which the government falls in response to a motion of no confidence because in both cases, the legal effect is the same: the government is considered to resign. ${ }^{89}$ On the other hand, however, the dissolution of the Assembly is only an opportunity for the president; the president can seize the moment to carry out the will of the Assembly, but no mechanism would allow the state of affairs to be mobilized against the president. ${ }^{90}$

In this constitutional judgment and interpretation, too, we notice impressive creativity on the part of the Court, whose findings rely more heavily on the spirit of the Constitution, its principles and comparative practice, than on its concrete provisions. ${ }^{91}$ Even here, then, as in its previous ruling, the Court relied more on the provisions' legal effects than on their language when it constructed the practice of forming the government with the incumbent legislature (after a motion of no confidence). Whether in terms of key actors in the process or of constitutional deadlines, the Court considered the practical effects of the

87 See Judgment in Case No KO103/14 (fn. 67), paras. 89-95.

88 See Judgment in Case No KO72/20 (fn. 85), paras. 273-345.

89

Ibid., paras. 434, 435, 436 .

Ibid., paras. 387, 389, 390.

91 Readers of the the full judgment will note that it is quite voluminous (162 pages) but will find the interpretation conveyed in the final decision at the end of the section wherein the court gives its answers. 
Constitution as it was written. This judgment (KO 70/20), filled with detailed comments throughout, and the previous judgment (KOI03/14), reflect the complete doctrine of a realized government-formation process. In light of the context in which the Constitutional Court has judged and decided, it is fair to say that the Court has managed to impose itself as a balance on the other governmental powers with its activism and has ensured its legitimacy ${ }^{92}$ with the decisions that we have analyzed herein.

\section{CONCLUSION}

This doctrinal legal analysis of the government-formation process of Kosovo allows us to draw several conclusions. First, we may reaffirm the notion that difficulties in forming post-election governments are characteristic of parliamentary states with proportional electoral systems and extreme party pluralism. Second, we can observe that when the constitutional provisions that govern the establishment of institutions of power are unclear, political crises may arise, owing to the different and sometimes opposed interpretations of competing political parties. This risk is especially potent in fragile parliamentary democracies. Moreover, the lack of constitutional clarity inhabits the realm of constitutional construction, which can be used for constitutional activism and affect the balance of power - though it can also defend the principle of a democratic majority. In Kosovo's case, even in light of the context in which the political crises in question unfolded, the Constitutional Court managed to establish a legitimate constitutional practice for government-formation, for both new and incumbent legislatures. This instance of judicial activism has proved healthy for the consolidation of democracy and the development of constitutional law, and as such, it has been welcomed by most of Kosovo's citizens. However, we caution that the newly developed practice must be constitutionalized by a democratic process of constitutional amendment. The interpretations and constructions of the Constitutional Court are law only until the Court's next interpretation, which may be provoked by other circumstances, and those next interpretations may prove to serve the narrow political interests of the most powerful groups rather than the welfare of the people.

92 On the legitimacy of judicial activism in context, see Bačić, P., Suvremeni konstitucionalizam i "nova" dioba vlasti, Zbornik radova Pravnog fakulteta u Splitu, vol. 46, no. 4, 2009, pp. 747-778. 


\section{BIBLIOGRAPHY}

Ambarkov, N., Constitutional Rigidity in the Countries with Consociational Democratic Approach - A Comparative Perspective, Horizons, vol. 22, 2018, pp. 143-154.

Bačić, P., Suvremeni Konstitucionalizam i "Nova" Dioba Vlasti, Zbornik radova Pravnog fakulteta u Splitu, vol. 46, no. 4, 2009, pp. 747-778.

Barnett, E. R., Restoring the Lost Constitution: The Presumption of Liberty, updated edition, Princeton University Press, 2004.

Beha, A.; Baliqi, B., 2014 Elections in Kosovo: A Retrospective, Department of Political Science of the University of Prishtina, September 2014.

Bergman, T., Constitutional Design and Government Formation: The Expected Consequences of Negative Parliamentarism, Scandinavian Political Studies, vol. 16, no. 4, 1993, pp. 285-304.

Bergman, T., Formation Rules and Minority Governments, European Journal of Political Research, vol. 23, no. 1, 1993, pp. 55-66.

Carvalho, A. S., Power-sharing: concepts, debates, and gaps, Janus.net e-journal of International Relations, no. 19, https://repositorio.ual.pt/handle/11144/2620 (1 June 2021).

Cheibub, J. A.; Martin, Sh.; Rasch, E. R., Investiture Rules and Formation of Minority Governments in European Parliamentary Democracies, Party Politics, vol. 27, no. 2, 2019, pp. 351-362, doi.org/10.1177/1354068819850447.

Cisneros, A. L., The Constitutional Interpretation/Construction Distinction: A Useful Fiction, Constitutional Commentary, vol. 27, 2010, pp. 71-92, available at: https://scholarship.law.umn.edu/concomm/615 (6 June 2021).

Crombez, Ch., Minority Governments, Minimal Winning Coalitions, and Surplus Majorities in Parliamentary Systems, European Journal of Political Research, vol. 29, no. 1, 1996, pp. 1-29.

Cyr, H., On the Formation of Government, Review of Constitutional Studies, vol. 22, no. 1, 2017, pp. 103-141.

Daniel, D.; Peter, V. R., The Duration of Cabinet Formation Processes in Western Multi-Party Democracies, British Journal of Political Science, vol. 28, no. 4, 1998, pp. 609-626.

Elkins, Z.; Ginsburg, T.; Melton, J., Constitute: The World's Constitutions to Read, Search, and Compare, Constitute Project, www.constituteproject.org (28 July 2021).

Fujiwara, Th.; Sanz, C., Rank Effects in Bargaining: Evidence from Government Formation, The Review of Economic Studies, vol. 87, no. 3, 2020, pp. 1261-1295. 
Gërxhaliu, S., Democracy as a Constitutional Value and its Mainstreaming in Court Cases, XXII International Congress on European and Comparative Constitutional Law, Vilnius, October 2019, available at: https://www.lrkt.lt/data/public/ uploads/2020/10/the-concept-of-democracy-web.pdf (16 September 2021).

Hasani, E., Judicial Review of Democracy. Maintenance of Democracy as a Functionalist Mission in the Jurisprudence of the Constitutional Court of Kosovo, Comparative Southeast European Studies, vol. 68, no. 4, 2020, pp. 530-553.

Hasani, E., The Role of the Constitutional Court in the Development of the Rule of Law in Kosovo, Review of Central and East European Law, vol. 43, no. 3, 2018, pp. 274-313.

Kelly, B. B., Power-Sharing and Consociational Theory, Palgrave Macmillan, 2019.

Korenica, F.; Doli, D., The Politics of Constitutional Design in Divided Societies: The Case of Kosovo, Croatian Yearbook of European Law and Policy, vol. 6, 2010, pp. 265-292.

Korenica, F.; Doli, D., Constitutional Rigidity in Kosovo: Significance, Outcomes, and Rationale, International Law Review Online Companion, vol. 2, no. 6, 2011, pp. 1-28, available at: https://digitalcommons.pace.edu/pilronline/22/ (17 June 2021).

Korenica, F.; Doli, D.; Rexha, A., Promising Early Years: The Transformative Role of the Constitutional Court of Kosovo, Analitika - Center for Social Research, Working Paper 4, 2016, http://www.legalpoliticalstudies.org/wp-content/ uploads/2016/09/Final-september-2016-Constitutional-Court-Kosovo-WP-1. pdf (16 September 2021).

Kostadinov, B., Formiranje vlade u razvijenim parlamentarnim demokracijama - SR Njemačka i Velika Britanija, Zbornik Pravnog fakulteta u Zagrebu, vol. 65, no. 6, 2015, pp. 915-930.

Laver, M.; Shepsle, A. K. (eds.), Making and Breaking Governments: Cabinets and Legislatures in Parliamentary Democracies, Cambridge University Press, 1996.

Ljiphart, A., Democracy in Plural Societies: A Comparative Exploration, Yale University Press, 1977.

Müller, W.; Strom, K. (eds.), Policy, Office, or Votes? How Political Parties Make Hard Choices, Cambridge University Press, 1998.

Podolnjak, R., Formiranje vlade u Republici Hrvatskoj u komparativnoj perspektivi - jedan prijedlog ustavne promjene, Pravni vjesnik, vol. 34, no. 3-4, 2018, pp. 55-84, https://doi.org/10.25234/pv/7618

Pula, B., Kosovo's Democracy at Risk?, Democracy for Development. Democracy Development Institute Research, available at: https://d4d-ks.org/en/papers/ kosovos-democracy-risk-kosovska-demokratija-pod-rizikom/? (16 July 2021). 
Qerimi, Q.; Qorolli, V., A Constitutional Tradition in the Making: The Presidents' Cases and the Role of Kosovo's Constitutional Court in the Process of Democratic Consolidation, Journal on International Constitutional Law, vol. 7, no. 1, 2013, pp. 49-57.

Rasch, E. B.; Martin, Sh.; Cheibub, J. A., Parliaments and Government Formation, Unpacking Investiture Rules, Oxford University Press, 2015.

Sejdiu, M., The Political (In)stability and Cabinet Duration in Kosova: Why Are Governments Short-Lived?, Group for Legal and Political Studies Policy Analysis, avalaible at: http:/www.legalpoliticalstudies.org/the-political-instability-and-cabinet-duration-in-kosova-why-are-governments-short-lived/ (23 July 2021).

Selimi, B., Minority Veto Rights in Kosovo's Democracy, The Age of Human Rights Journal, no. 12, 2019, pp. 148-157.

Shala, Xh., Efekti i sistemit proporcional te sistemi politik dhe formimi $i$ institucioneve të Kosovës, DPhil thesis, European University of Tirana, 2018.

Solum, B. L., Originalism and Constitutional Construction, Georgetown Law Faculty Publications and Other Works, vol. 28, 2013.

Solum, B. L., Originalism Versus Living Constitutionalism: The Conceptual Structure of the Great Debate, Northwestern University Law Review, vol. 113, no. 6, 2019, pp. 1278-1280.

Tunheim, J., Rule of Law and the Kosovo Constitution, Minnesota Journal of International Law, vol. 18, no. 2, 2009, pp. 371-379.

Warwick, P., The Durability of Coalition Governments in Parliamentary Democracies, Comparative Political Studies, vol. 11, no. 4, 1979, pp. 465-498.

\section{REGULATIONS AND DOCUMENTS}

Constitution of Albania, www.constituteproject.org (AL)

Constitution of Croatia, www.constituteproject.org (HR)

Constitution of Kosovo (2008), https://gzk.rks-gov.net/ActDetail.aspx?ActID=3702 (XK)

Constitution of Serbia, www.constituteproject.org (RS)

Constitution of Latvia, www.constituteproject.org (LV)

Constitution of Slovenia, www.constituteproject.org (SI)

Constitution of Estonia, www.constituteproject.org (EE)

Constitution of North Macedonia (English version), https://www.sobranie.mk/ the-constitution-of-the-republic-of-macedonia.nspx (MK) 
Constitution of Lithuania, http://www.regione.taa.it/biblioteca/minoranze/ lituanial.pdf (LT)

Constitution of Lebanon, www.constituteproject.org (LB)

Constitution of Belgium (English translation), http://hrlibrary.umn.edu/research/ belgium-constitution.html (BG)

Constitution of Montenegro, www.constituteproject.org (ME)

Rules of Procedures of Kosovo Assembly, https://www.assembly-kosova.org/ Uploads/Data/Files/6/Rr_K_RK_29_04_2010_1_EDbu8aqXYd.pdf

\section{JUDGMENTS AND OTHER DECISIONS}

Kosovo Constitutional Court Judgment in Case No. K0103/14, I July 2014, https://gjk-ks.org/wp-content/uploads/vendimet/gjkk_ko_103_14_ang.pdf (19 September 2021)

Kosovo Constitutional Court Judgment in Case No. KOl19/14, 26 August 2014, https://gjk-ks.org/wp-content/uploads/vendimet/gjk_ko_119_14_ang.pdf (18 September 2021)

Kosovo Constitutional Court, Dissenting Opinion of Judge Robert Carolan, https://gjk-ks.org/wp-content/uploads/vendimet/gjkk_ko_103_14_mm_shq. pdf (8 September 2021)

Constitutional Court of the Republic of Kosovo, Judgement in Case No. KO72/20, I June 2020, https://gjk-ks.org/wp-content/uploads/2020/06/ ko_72_20_agj_ang.pdf (25 September 2021)

Constitutional Court of the Republic of Kosovo, DECISION ON INTERIM MEASURE III Case No. K01 19/14, 17 July 2014, https:/gjk-ks.org/wp-content/ uploads/vendimet/KOl19-14_VMP_ANG.pdf (19 September 2021)

\section{INTERNET SOURCES}

Kosovo Government, https://kryeministri.rks-gov.net/en/prime-minister-thaciwe-the-three-leaders-of-our-parties-pdk-ldk-and-akr-have-reached-an-agreement-for-a-reformed-kosovo-a-european-kosovo/ (13 August 2021)

Kosovo Assembly, https://www.assembly-kosova.org/Uploads/Data/Files/6/ Rr_K_RK_29_04_2010_1_EDbu8aqXYd.pdf (8 September 2021)

Central Election Comision of Kosovo, https://www.kqz-ks.org/wp-content/ uploads/2019/11/3.Ndarja-e-ul\%C3\%ABseve-n\%C3\%AB-Kuvend-Subjektet-dhe-kandidat\%C3\%ABt-e-zgjedhur-l.pdf (23 September 202I) 
'Bie Qeveria Kurti' Epoka e Re (25 March 2020), https:/www.epokaere.com/ bie-qeveria-kurti/ (24 September 2021)

'Kosovo Parties Sign Agreement on Coalition Government Led by Albin Kurti’ Exit news (20.02.2020), https:/exit.al/en/2020/02/02/kosovo-parties-sign-agreement-on-coalition-government-led-by-albin-kurti/ (24 September 2021)

'Ky është teksti i mocionit të mosbesimit ndaj Qeverisë Kurti i përgatitur nga LDK-ja (Dokument)' Evropaa e lire (3 February 2020), https://www.evropaelire.org/a/30508373.html (24 September 2021) 
Sažetak

\section{Behar Selimi* \\ Murat Jashari**}

\section{TUMAČENJE USTAVA I USTAVNA KONSTRUKCIJA FORMIRANJA VLADE NA KOSOVU}

U ovome članku analiziraju se ustavne odredbe i praksa kosovskog formiranja vlade u dva scenarija: nakon parlamentarnih izbora i nakon izglasavanja nepovjerenja. Cimbenici koji izrazito kompliciraju taj proces su proporcionalni izborni sustav, ekstremni stranački pluralizam i dvosmislene ustavne odredbe. Ostavljajući po strani prva dva čimbenika, koji su do sada odolijevali nastojanjima da ih se promijeni, autori tvrde da je ustavno pravo koje se bavi procesom formiranja vlasti doživjelo i proceduralne i materijalne promjene kao rezultat tumačenja i odluka Ustavnog suda. Autori nadalje primjećuju da su te promjene ustavne konstrukcije, a ne klasična ustavna tumačenja, te opisuju novu, rezultirajuću praksu kao legitimiranu bez ustavne promjene. Ova ustavna tumačenja i konstrukcije, njihove moguće alternative te relevantne ustavne odredbe analiziraju se doktrinarnim pravnim istraživanjem. Uzimajući u obzir činjenicu da se ustavne presude mogu reinterpretirati $i$ biti zloupotrijebljene privremenim ad hoc koalicijama, koje se temelje na trenutačnim uskim stranačkim interesima, može se pretpostaviti da će to stvarati dodatne nestabilnosti u budućnosti. Stoga autori smatraju da je izmjena ustava najbolje osiguranje od političke i ustavne krize kada je u pitanju formiranje vlasti, bilo nakon izbora, bilo s istim zakonodavnim tijelom. Autori se nadaju da će ovaj rad pridonijeti obogaćivanju ustavne prakse formiranja parlamentarnih vlada i razvoju doktrine tumačenja ustava.

Ključne riječi: tumačenje ustava, ustavna konstrukcija, formiranje vlade, Ustav Kosova, ustavni sud

* Dr. sc. Behar Selimi, izvanredni profesor Pravnog fakulteta UBT Collegea, Lagjja Kalabria, 10000 Priština, Kosovo; bselimi@hotmail.com;

ORCID ID: orcid.org/0000-0002-3070-6720

** Dr. sc. Murat Jashari, docent Pravnog fakulteta Sveučilišta u Prištini, Rr. "Agim Ramadani”, 10000 Priština, Kosovo; muratjashari@hotmail.com.

ORCID ID: orcid.org/0000-0003-1502-8279 